\title{
WUJUD IMPLEMENTASI KEARIFAN LOKAL DALAM SIKLUS KEHIDUPAN PADA MASYARAKAT GORONTALO (STUDI PADA TRADISI PERNIKAHAN DAN TRADISI MOLONTALO (TUJUH BULANAN)
}

\author{
Nurhayati Tine \\ Musafir Pabbabari \\ Susdiyanto \\ Abd. Kadir Ahmad \\ Universitas Negeri Gorontalo
}

\begin{abstract}
Abstrak: Tulisan ini akan mengelaborasi tentang wujud implementasi nilai-nilai pendidikan Islam dalam kearifan lokal masyarakat Gorontalo terkait dengan siklus kehidupan. Jenis penelitian adalah deskriptif kualitatif dengan jenis studi kasus. Penelitian ini dilakukan di Gorontalo, dan difokuskan pada adat-istiadat yang masih berlaku di Gorontalo. Adapun pendekatan yang digunakan dalam penelitian ini adalah pendekatan fenomenologi, etnografi, sosio-edukatif, dan hukum Islam.

Sumber data primer penelitian ini diperoleh dari individu-individu yang berkompeten dalam hal tradisi dan adat-istiadat masyarakat Gorontalo baik dari lingkungan akademisi, budayawan, tokoh adat, tokoh agama, maupun tokoh masyarakat lainnya yang masih terlibat aktif dalam berbagai pelaksanaan ritus budaya di Gorontalo. Teknik pengumpulan data dalam penelitian ini dilakukan dengan tiga cara, yaitu: (1) observasi partisipasi; (2) wawancara mendalam; dan (3) penggunaan dokumen. Penelitian ini menggunakan 3 (tiga) instrumen utama yaitu: peneliti sendiri (human instrument); pedoman observasi; dan pedoman wawancara. Analisa data dalam penelitian ini bersifat deskriptif (deskriptif analitis) dan analisis komparatif. Untuk menarik kesimpulan, data yang dihimpun diolah melalui proses reduksi, sajian data, dan verifikasi.

Wujud implementasi nilai-nilai pendidikan Islam dalam kearifan lokal masyarakat Gorontalo terkait dengan siklus kehidupan ditemukan pada beberapa makna edukatif yang diperoleh dari prosesi adat moponika/lenggota lo pohutu (pernikahan) dan molontalo (tujuh bulanan) Masing-masing dari prosesi yang terkait dengan siklus kehidupan tersebut memuat kearifan lokal berupa: 1) perlunya meninggalkan sifat-sifat tercela; 2) penyucian diri dari dosa lahir dan batin; 3) pentingnya menjaga kehalalan dari setiap harta yang dimiliki; 4) memperkuat pendirian, keimanan dan ketakwaan; 5) mempertahankan kesucian dan kehormatan diri; 6) kerendahan hati; 7) hidup hemat; 8) penataan diri mulai dari remaja sampai berumah tangga; 9) menjaga nama baik keluarga; 10) tidak meminta-minta; 11) keberkahan dan kebahagiaan hidup sebagai sasaran akhir; 12) penghargaan terhadap tamu dan kerabat; 13) serta pentingnya kesabaran dalam menjalani kehidupan.
\end{abstract}




\section{Keywords: Kearifan Lokal, moponika/lenggota lo pohutu (pernikahan), molontalo (tujuh bulanan)} I. PENDAHULUAN

Budaya lokal adalah suatu proses penumbuhan kreatif diri seorang manusia yang aktual dalam menghadapi tantangan sosial dalam penyesuaian keadaan daerah asal. Jika dilihat dari beberapa fenomena yang hingga sekarang masih terlihat dengan nyata di tengah masyarakat, ada gejala penguatan terhadap praktik penyelenggaraan tradisi lokal, seirama dengan semakin intensifnya gerakan pemurnian Islam, fundamentalisme, dan pengembangan Islam dewasa ini. Kontak kebudayaan di dalam proses ekspansi nilai-nilai ajaran Islam dengan kebudayaan masyarakat menyebabkan adanya proses tarik menarik antara keduanya yang tak jarang menghasilkan dinamika budaya masyarakat setempat. Kemudian, yang terjadi ialah sinkretisme dan atau akulturasi budaya, seperti; praktik meyakini iman di dalam ajaran Islam akan tetapi masih mempercayai berbagai keyakinan lokal.

Dengan demikian, tradisi lokal diposisikan berlawanan dengan tradisi purifikasi yang menekankan pada pengamalan keagamaan yang harus bersumber dari nilai-nilai ajaran Islam. Bahkan, tidak dapat dipungkiri, pergulatan ini berakibat terhadap persoalan interaksi di antara masyarakat dalam bingkai sosial, budaya, dan politik. Satu hal yang jelas adalah bahwa setiap tradisi dilestarikan melalui proses pelembagaan yang dilakukan oleh kaum elitnya, yang sesungguhnya dimaksudkan agar tradisi yang memiliki rangkaian panjang dengan tradisi sebelumnya tidak hilang begitu saja, akan tetapi menjadi bagian tak terpisahkan dari generasi ke generasi berikutnya.

Siklus tradisi dalam medan budaya masyarakat yang banyak dijumpai sampai saat ini pada dasarnya merupakan suatu bentuk penghayatan yang bersifat transkosmik terhadap keyakinan adanya kekuatan yang Mahadahsyat untuk mengubah kehidupan mereka. Sehingga yang terjadi adalah terkonstruksinya berbagai prosesi atau ritual yang dimaksudkan untuk memperoleh berkah dari-Nya.

Dalam realitas kehidupan masyarakat, sebagian besar umat Islam masih banyak yang menerapkan amalan-amalan atau tradisi dan adat istiadat, baik itu mengenai pembaiatan, perkawinan, kehamilan sampai pada kelahian anak. Masalah ini tampaknya perlu menjadi perhatian agar umat tidak terjerumus ke dalam upacara yang menyalahi syariat Islam. Sebab, di tengah masyarakat yang masih feodalis dan masih meyakini kekuatan-kekuatan mistik, cukup banyak ditemukan upacara-upacara yang cenderung menjerumuskan mereka ke dalam kesyirikan meskipun mereka mengaku sebagai Muslim. Misalnya dapat dilihat pada tradisi memasang pelita/lampu teplok di atas ari-ari bayi yang ditanam atau membuat sesaji dengan bunga dan makanan tertentu untuk memudahkan perempuan melahirkan, atau menggantungkan azimat di leher bayi agar lepas dari gangguan penyakit dan masih banyak lagi.

Pada dasarnya suatu kepercayaan diungkapkan dengan upacara-upacara yang merupakan perilaku pemujaan atau ketaatan yang dilakukan untuk menunjukkan komitmen terhadap suatu kepercayaan yang dianut. Dengan upacara-upacara tersebut, setiap orang dibawa ke keadaan dimana getaran-getaran jiwa terhadap keyakinan mereka menjadi lebih kuat dari dalam. Dengan demikian, upacara tradisonal pada dasarnya berfungsi sebagai media komunikasi antara manusia dengan kekuatan lain yang ada di luar diri manusia.

Merujuk dari uraian tersebut perlu dipahami bahwa untuk menghadapi tahap pertumbuhannya yang baru, maka dalam lingkaran hidupnya manusia juga memerlukan regenerasi semangat kehidupan sosial. Oleh karena itu, rangkaian ritus dan upacara sepanjang tahap-tahap pertumbuhan oleh banyak kebudayaan sangatlah penting, misalnya dalam upacara pembaiatan, upacara perkawinan, hamil tua, upacara saat anak tumbuh, upacara memotong rambut pertama, upacara keluar gigi yang pertama, upacara penyentuhan si bayi untuk pertama kali, upacara sunatan, upacara kematian dan sebagainya.

Hal yang paling penting dalam upacara tersebut adalah adanya mekanisme-mekanisme atau proses-proses pelaksanaan upacara. Selain itu, terdapat juga lambang-lambang, sesaji atau simbol-simbol upacara yang memiliki makna dan nilai tersendiri bagi pelaksananya. 
Mekanisme-mekanisme serta simbol-simbol, lambang-lambang dan atau sesaji tersebut tidak dibakukan secara formal, tetapi diyakini, diakui, dipatuhi oleh masyarakat penganutnya. Sehingga menjadi sosial kontrol dan pedoman berperilaku dalam masyarakat pendukungnya.

Sedangkan adat sebagai bagian dari sistem budaya mencakup kebiasaan individu dan kebiasaan sosial, kebiasaan individu jika dipahami dan dilakukan berulang kali oleh kelompok masyarakat dengan arti dan simbol yang sama, maka jadilah adat kebiasaan itu sebagai tradisi.

Pergantian waktu dan perubahan fase kehidupan bagi masyarakat tradisional adalah saat-saat penting yang perlu dicermati dan diwaspadai. Untuk itu, mereka mengadakan ritus dan perayaan, yaitu upacara peralihan yang berupa selamatan, makan bersama, prosesi dengan benda-benda keramat dan sebagainya. Kehadiran Islam sebagai agama baru dalam suatu kelompok masyarakat tidak lantas menghilangkan ritus atau tradisi yang sudah terbentuk. Ritual-ritual ini tetap dilanjutkan, hanya isinya diubah dengan unsur-unsur dari ajaran Islam, maka terjadilah islamisasi. Sejalan dengan itu, keanekaragaman budaya yang ada pada masyarakat Indonesia sangat banyak dan menarik untuk diamati dan diteliti, karena di dalamnya terkandung makna dan nilai-nilai berharga yang disampaikan secara khas dan unik melalui simbol-simbol yang diciptakan oleh manusia itu sendiri.

Berkenaan dengan itu, tidak perlu lagi ditegaskan bahwa unsur-unsur budaya lokal yang dapat atau harus dijadikan sumber hukum ialah yang sekurang-kurangnya tidak bertentangan dengan prinsip-prinsip Islam. Unsur-unsur yang bertentangan dengan prinsip Islam dengan sendirinya harus dihilangkan dan diganti. Inilah makna kehadiran Islam di suatu tempat atau negeri. Karena itu setiap masyarakat Islam mempunyai masa jahiliahnya sendiri yang sebanding dengan apa yang ada pada bangsa Arab. Masa jahiliah suatu bangsa atau masyarakat ialah masa sebelum datangnya Islam di situ, yang masa itu diliputi oleh praktik-praktik yang berlawanan dengan ajaran tauhid serta ajaran-ajaran lain dalam Islam seperti, tata sosial tanpa hukum (laotik), takhayul, mitologi, feodalisme, ketidakpeduliaan kepada nasib orang kecil yang tertindas, pengingkaran hak asasi, perlawanan terhadap prinsip persamaan umat manusia dan seterusnya. Semuanya harus ditiadakan dan diganti dengan ajaran-ajaran Islam tentang tauhid atau paham Ketuhanan Yang Maha Esa (dengan implikasi terkuat anti pemujaan gejala alam dan sesama manusia (cultism)), tertib hukum, rasionalitas, penilaian berdasarkan kenyataan dan pandangan ilmiah, penghargaan sesama manusia atas dasar prestasi dan hasil kerja, keadilan sosial, paham persamaan antar umat manusia (al-musāwah, egalitarianisme), dan seterusnya. ${ }^{1}$

Sebelum masuknya agama selain Islam di wilayah Gorontalo, leluhur masyarakat Gorontalo telah memiliki dan melaksanakan keyakinan agamanya secara arif. Istilah animisme dan dinamisme sebagai agama yang dianut nenek moyang masyarakat Gorontalo sebagaimana ditulis dalam sejarah harus dipandang sebagai taktik penjajah dalam rangka mendiskreditkan dan pembunuhan karakter terhadap masyarakat Gorontalo sendiri. Sebab, seperti diketahui, sejarah dibuat oleh ahli-ahli dari bangsa penjajah serta menggunakan catatan-catatan perjalanan dari penjelajah-penjelajah bangsa Eropa. Sampai saat ini, nilai-nilai islami dalam budaya dan peradaban Gorontalo termasuk sastranya sudah menyatu dengan adat istiadat yang berlaku. Nilai-nilai itu sudah melatari pengetahuan dan pola perilaku masyarakatnya.

Rangkaian ritus budaya yang terbentuk di tengah masyarakat Gorontalo mengindikasikan tentang kuatnya paham masyarakat terhadap kekuatan dan nilai tradisi. Dalam kaitan itu, Kluckhon dalam asumsi teorinya menyatakan bahwa dalam rangka sistem budaya dari tiap kebudayaan, ada rangkaian konsep-konsep yang abstrak dan luas ruang lingkupnya, yang hidup dalam alam pikiran dari sebagian besar warga masyarakat, mengenai apa yang harus dianggap penting dan bernilai dalam hidup ini. Dari asumsi tersebut dapat ditarik sebuah makna bahwa individu sebagai unsur penting dalam masyarakat itu selalu bergerak dan berinteraksi untuk mengejar tujuan hidupnya dengan memanfaatkan media masyarakat. Salah satu orientasi kemasyarakatan lahir disebabkan pemikiran dan intiuisi manusia untuk menyalurkan rasa keinginan hidup bersama dalam kedamaian. Dengan demikian dapat dikatakan bahwa sistem

${ }^{1}$ Nurcholish Madjid, Nurcholish Madjid, Doktrin dan Peradaban; Sebuah Telaah Kritis tentang Masalah Keimanan, Kemanusiaan, dan Kemodernan (Jakarta: t.p., t.th.), h. 550. 
nilai budaya itu juga berfungsi sebagai pedoman orientasi bagi segala tindakan manusia dalam hidupnya. ${ }^{2}$

Nilai budaya masyarakat yang berwujud dalam tradisi merupakan hasil sebuah proses yang berdimensi waktu lampau, kini, dan waktu yang akan datang. Hal ini sesuai dengan konsep diri serta kesadaran subjektif masyarakat Gorontalo yang hadir berdasarkan perguliran waktu dan kekuatan yang saling berkaitan. Perpaduan antar unsur-unsur sosial dan agama terjalin menjadi kesatuan-kesatuan aktual yang diabadikan menjadi ritual adat oleh karena lahir dari proses panjang yang bersifat adaptif dan integratif. Hubungan timbal balik tersebut berproses secara adaptif dan saling berintegrasi dalam struktur sosial masyarakat Gorontalo secara umum.

Tulisan ini akan mengelaborasi tentang wujud implementasi nilai-nilai pendidikan Islam dalam kearifan lokal masyarakat Gorontalo terkait dengan siklus kehidupan.

\section{KAJIAN TEORETIK}

\section{A. Pengertian Kearifan Lokal}

Manusia menciptakan budaya dan lingkungan sosial mereka sebagai adaptasi terhadap lingkungan fisik dan biologisnya. Kebiasaan-kebiasaan, praktik, dan tradisi diwariskan dari generasi ke generasi. Pada gilirannya kelompok atau ras tersebut tidak menyadari dari mana asal warisan kebijaksanaan tersebut. Generasi berikutnya terkondisikan menerima "kebenaran" tentang nilai, pantangan, kehidupan, dan standar prilaku. Individu-individu cenderung menerima dan percaya apa yang dikatakan budaya mereka. Di saat itulah muncul apa yang disebut sebagai kearifan lokal yang kemudian menjadi pegangan hidup bagi suatu komunitas tertentu.

Kearifan lokal merupakan suatu istilah yang mencuat ke permukaan dengan mengadopsi prinsip, nasehat, tatanan, norma dan perilaku leluhur pada masa lampau yang masih sangat urgen untuk diaplikasikan dalam menata berbagai fenomena yang muncul. ${ }^{3}$ Kearifan lokal merupakan bagian dari konstruksi budaya. Dalam pandangan John Haba dalam Irwan Abdullah, kearifan lokal "mengacu pada berbagai kekayaan budaya yang tumbuh dan berkembang dalam sebuah masyarakat yang dikenal, dipercayai, dan diakui sebagai elemen-elemen penting yang mampu mempertebal kohesi sosial di antara warga masyarakat". ${ }^{4}$

Kearifan lokal yang dalam bahasa Inggris disebut local wisdom atau adakala juga disebut dengan kata local genius, merupakan sebuah istilah yang mulai populer digunakan oleh para pengkaji ilmu sosial pada dua dasawarsa terakhir ini. Terminologi ini mengandung suatu semangat untuk melihat, memikirkan, dan mempergunakan kembali nilai-nilai, norma dan adat yang berlaku di suatu masyarakat yang telah terwariskan secara turun temurun. Istilah ini mengandung dua kata, "kearifan" (wisdom) yang bermakna kemampuan menggunakan akal pikiran dan hati dalam menyikapi sesuatu, dan "lokal" yang menunjukkan kepada lokasi atau suatu tempat tertentu. ${ }^{5}$

\footnotetext{
${ }^{2}$ Koentjaraningrat, Metode-metode Penelitian Masyarakat (Jakarta: Gramedia, 1981), h. 77.

${ }^{3}$ Muhammad Ramli, "Sinergitas Kearifan Lokal Masyarakat Bugis dalam Impelementasi Kebijakan Publik di Kabupaten Sidenreng Rappang", Disertasi, (Makassar: Program Pascasarjana Universitas Hasanuddin, 2008), h. 24-25.

${ }^{4}$ Irwan Abdullah, dkk., Agama dan Kearifan Lokal dalam Tantangan Global (Cet. II; Yogyakarta: Sekolah Pascasarjana UGM dan Pustaka Pelajar, 2008), h. 7.

${ }^{5}$ Fariani, "Nilai Pendidikan dalam Kearifan Lokal Permainan Tradisional Anak Suku Batak dan Melayu", dalam Buletin Haba, Nomor 72 (Banda Aceh: Balai Pelestarian Nilai Budaya, 2014).
} 
Dalam Kamus Inggris Indonesia, ${ }^{6}$ local berarti setempat, sedangkan wisdom (kearifan) sama dengan kebijaksanaan. Secara umum maka local wisdom (kearifan setempat atau kearifan lokal) dapat dipahami sebagai, gagasan-gagasan setempat (local) yang bersifat bijaksana, penuh kearifan, bernilai baik, yang tertanam dan diikuti oleh anggota masyarakatnya. ${ }^{7}$ Dengan demikian, kearifan lokal adalah sesuatu yang memang telah hidup dan terwariskan dalam masyarakat dan digunakan oleh masyarakat tersebut sebagai alat berinteraksi dalam kehidupan sehari-hari untuk terwujudnya interaksi sosial ideal yang jauh dari konflik.

Terminologi kearifan lokal juga mengandung makna sebagai sebuah "perlawanan" terhadap arus globalisasi yang merambah relung-relung budaya manusia ke seluruh dunia, yaitu masuknya budaya "Barat" ke wilayah budaya penduduk di benua Asia dan Afrika khususnya pasca era kolonialisme. Terminologi kemodernan sering dikaitkan dengan "budaya Barat" yang seolah-olah agar menjadi modern seseorang haruslah berbudaya orang Barat. Ketika menjadi modern dipahami adalah sama dengan menjadi barat, muncul banyak masalah dalam kehidupan sosial di masyarakat non Barat. Karenanya, istilah kearifan lokal muncul bersamaan dengan populernya beberapa istilah lain, seperti istilah back to nature (kembali ke alam) atau back to basic (kembali ke budaya asal) sebagai pernyataan re-eksistensi budaya masyarakat non Barat.

Dengan demikian, kearifan lokal dapat dipahami sebagai sebuah cara pandang yang mengandung nilai, norma, aturan adat yang telah membumi dan terwariskan dari satu generasi ke generasi lainnya dalam sebuah entitas budaya (masyarakat). Jika kebudayaan dipahami sebagai keseluruhan hasil karya manusia yang berwujud ide (gagasan), aktivitas, atau benda, maka kearifan lokal adalah bagian dari kebudayaan yang kecenderungannya mengambil bentuk berupa ide serta aktivitas.

Dalam disiplin antropologi dikenal istilah local genius. Local genius ini merupakan istilah yang mula pertama dikenalkan oleh Quaritch Wales. Para antropolog membahas secara panjang lebar pengertian local genius ini. Antara lain Haryati Soebadio mengatakan bahwa local genius adalah juga cultural identity, identitas/kepribadian budaya bangsa yang menyebabkan bangsa tersebut mampu menyerap dan mengolah kebudayaan asing sesuai watak dan kemampuan sendiri. ${ }^{8}$ Sementara Moendardjito mengatakan bahwa unsur budaya daerah potensial sebagai local genius karena telah teruji kemampuannya untuk bertahan sampai sekarang. ${ }^{9}$ Ciricirinya adalah: 1) mampu bertahan terhadap budaya luar; 2) memiliki kemampuan mengakomodasi unsur-unsur budaya luar; 3) mempunyai kemampuan mengintegrasikan unsur budaya luar ke dalam budaya asli; 4) mempunyai kemampuan mengendalikan; dan 5) mampu memberi arah pada perkembangan budaya.

Dalam kajian antropologi disebutkan bahwa semua kebudayaan suku bangsa mempunyai "fokus kebudayaan", yang mana ia merupakan satu unsur budaya yang amat dominan dan mempengaruhi unsur-unsur budaya lainnya. Dalam kebudayaan Bali, misalnya, yang menjadi fokus kebudayaannya adalah unsur kesenian karena unsur

${ }^{6}$ I. Markus Willy, M. Dikkie Darsyah, dan Mieke Ch, Kamus Inggris Indonesia-Indonesia Inggris (Surabaya: Penerbit Arloka, 1996), h. 201 dan 403.

${ }^{7}$ Sartini, "Menggali Kearifan Lokal" dalam Jurnal Filsafat, Jilid 37, Nomor 2 (Agustus 2004), h. 111.

${ }^{8}$ Ayatruhaedi, Kepribadian Budaya Bangsa (Local Genius) (Jakarta: Pustaka Jaya, 1986), h. 18-

\footnotetext{
${ }^{9}$ Ayatruhaedi, Kepribadian Budaya Bangsa, h. 40-41.
} 
ini mempengaruhi unsur-unsur budaya lainnya, seperti agama, sistem mata pencaharian, sistem peralatan hidup, dan unsur budaya lainnya. ${ }^{10}$

Pengertian lain yang lebih terperinci tentang kearifan lokal adalah, kebenaran yang telah mentradisi atau ajeg dalam suatu daerah. Kearifan lokal merupakan perpaduan antara nilai-nilai suci firman Tuhan dan berbagai nilai yang ada. Kearifan lokal terbentuk sebagai keunggulan budaya masyarakat setempat maupun kondisi geografis dalam arti luas. Kearifan lokal merupakan produk budaya masa lalu yang patut secara terus-menerus dijadikan pegangan hidup. Meskipun bernilai lokal tetapi nilai yang terkandung di dalamnya dianggap sangat universal. ${ }^{1}$

Kearifan lokal dimaknai juga sebagai adat yang memiliki kearifan atau al- ‘̄adah al-ma'rifah, yang dilawankan dengan al-'àdah al-jahiliah. Kearifan adat dipahami sebagai segala sesuatu yang didasari pengetahuan dan diakui akal serta dianggap baik oleh ketentuan agama. ${ }^{12}$ Adat kebiasaan pada dasarnya teruji secara alamiah dan niscaya bernilai baik, karena kebiasaan tersebut merupakan tindakan sosial yang berulang-ulang dan mengalami penguatan (reinforcement).

Secara konseptual, kearifan lokal dan keunggulan lokal merupakan kebijaksanaan manusia yang bersandar pada filosofi nilai-nilai, etika, cara-cara dan perilaku yang melembaga secara tradisional. Kearifan lokal adalah nilai yang dianggap baik dan benar sehingga dapat bertahan dalam waktu yang lama dan bahkan melembaga. ${ }^{13}$

\section{B. Bentuk-Bentuk Ritus Adat Gorontalo}

Berdasarkan benda-benda peninggalan adat tradisonal Gorontalo dapat dikatakan bahwa sebelum Islam datang, kepercayaan penduduk bersifat animisme. Berkaitan dengan hal ini, kebiasaan-kebiasaan tradisional tersebut masih tampak terutama untuk upacara-upacara memanggil ruh halus dan sebutan pemimpin upacara ritual tersebut seperti panggoba, wombua dan talenga, sebutan yang diberikan kepada dukun atau dalang dalam upacara pemanggilan ruh. Demikian pula masih terdapat adanya kepercayaan dan ketaatan mereka mematuhi apa yang tertuang dalam hasil sastra lisan sebagai pencerminan masyarakat lama. Contoh yang nyata hingga dewasa ini ialah masih adanya kepercayaan akan kekuatan gaib. Apakah ia sebagai pejabat atau bukan, ia masih memerlukan benda-benda yang dianggap mempunyai kekuatan, seperti azimat penjaga badan, penangkal penyakit, atau penangkal pencuri supaya tidak masuk ke rumah, benda yang dipakai supaya kebal, dan memuja arwah nenek moyang.

Tradisi yang terdapat di daerah Gorontalo diberlakukan sama. Tradisi tersebut terbagi atas beberapa jenis: 1) Tradisi yang berhubungan dengan adat istiadat yang menyangkut upacara pernikahan, penobatan dan penyambutan pejabat, pemakaman, pengguntingan rambut serta pembeatan; 2) Tradisi yang berhubungan dengan kesenian yang menyangkut zikir (dikili), burdah (buruda), dana-dana dan zamrah; 3) Tradisi yang berhubungan dengan gerak atau olahraga, tarian seperti langga, longgo; 4) Tradisi yang berhubungan dengan sastra. Tradisi sastra ini berdasarkan penelitian menemukan

\footnotetext{
${ }^{10}$ Koentjaraningrat, Pengantar Antropologi (Jakarta: Universitas Indonesia Press, 2004), h. 33.

${ }^{11}$ I Ketut Gobyah "Berpijak pada Kearifan Lokal" dalam http://www. balipos.co.id, diakses pada tanggal 14 Desember 2016.

${ }^{12}$ Sartini, "Menggali Kearifan Lokal”, h. 112; "Penjelasan Tentang 'Urf” dalam Pikiran Rakyat terbitan 6 Maret 2003.

${ }^{13}$ S. Swarsi Geriya dalam "Menggali Kearifan Lokal untuk Ajeg Bali" dalam Iun, http://www.balipos.co.id.
} 
adanya lima belas ragam sastra lisan yang diigunakan masyarakat dalam kegiatan seni dan budaya. Tradisi sastra ini sangat erat hubungannya dengan adat dan kehidupan dalam masyarakat baik dalam bentuk prosa maupun puisi.

Adat merupakan salah satu budaya bangsa yang sangat berharga yang dimiliki oleh daerah di seluruh Indonesia. Adat Gorontalo mempunyai norma atau kaidah yang menjadi pegangan dan petunjuk dalam pergaulan hidup di tengah-tengah masyarakat yang terdiri dari: (a) Wu'udu (peraturan kebiasaan) yang mempunyai sangsi tapi tidak diletakkan oleh hukum. Contoh, Wulea lo lipu (camat), yang tidak memakai kopiah tidak boleh dihormati secara tubo (penghormatan secara adat) oleh Tauda'a (kepala desa). (b) Aadati (wu'udu yang mempunyai sangsi) yang dalam masyarakat adat Gorontalo disebut hukum adat. (c) Tinepo (peraturan kesopanan) yaitu pedoman untuk bertingkah laku dalam pergaulan sehari-hari guna penghormatan kepada sesama. Contoh, adat penyambutan terhadap pejabat tinggi negara yang tidak masuk dalam pulanga (jabatan dalam adat). (d) Tombula'o (peraturan kesusilaan) yang merupakan petunjuk bagi setiap orang untuk tidak saja mengetahui, tapi harus dapat membedakan apa yang baik dan yang buruk. Kaidah ini mencegah perbuatan sewenang-wenang dari pihak penguasa dan mencegah tindakan apatis dari yang dikuasai. (e) Butoqo (hukum) adalah hukum dari Olongia (raja), Baate (pemangku adat), yang merupakan petunjuk menyelesaikan sesuatu perkara yang terjadi dalam masyarakat. ${ }^{14}$

Segala sesuatu yang menyangkut adat sudah teratur dan setiap warga masyarakat tinggal melaksanakan. Terkenal semboyan: 'aadati ma dilidilito bolomopo'aito, aadati mahunti-huntingo bolomopodembingo, aadati ma dutu-dutu bolomopohutu'. Artinya adat sudah dipolakan tinggal menyambungkan, adat sudah digunting tinggal menempelkan, adat sudah siap tinggal melaksanakan. ${ }^{15}$

Sebelum masuknya pengaruh Islam pada masyarakat Gorontalo, adat istiadat dan budaya masyarakat daerah dipengaruhi oleh filsafat naturalistik, dimana nilai-nilai dan norma-norma budaya bersumber dari fenomena alam semesta. Pada masa Eyato menjadi raja persatuan $u$ duluwo limo lo Pohalaqa dan raja kesatuan GorontaloLimboto agama Islam resmi menjadi agama kerajaan.

Adat sebagai wujud kebudayaan yang disebut juga sistem budaya adalah sama dengan prinsip adat Aceh dan Minangkabau yakni "adat bersendi syarak, dan syarak bersendi Kitabullah (Alquran)". Istilah ini dalam bahasa Gorontalo disebutkan "adati hula-hula'a to sara'a, sara'a hula-hula'a to kuru'ani'. Dalam kenyataan sejarah istilah ini tidak muncul dengan sendirinya, akan tetapi melalui suatu proses sejarah. Pada masa Gorontalo diperintah oleh Sultan Amai (1523-1550) slogannya adalah "sara'a topa-topango to adati" atau syarak bertumpu pada adat. ${ }^{16}$ Raja Gorontalo yang pertama kali menerima tentang risalah Islam masuk ke kerajaan Gorontalo adalah Sultan Amai pada awal abad ke-16 atau tahun $1525 .{ }^{17}$ Pengembangan agama Islam di Gorontalo selalu didasarkan atas rumusan yang dikatakan penuh kearifan itu. Tokoh yang sangat berperan dengan pemikirannya yang religius Islami adalah istri Amai sendiri yang bernama Owutango putri raja Palasa. Pada awalnya untuk bisa diperistri

\footnotetext{
${ }^{14}$ Moh. Karmin Baruadi, "Sendi Adat dan Eksistensi Sastra; Pengaruh Islam dalam Nuansa Budaya Lokal Gorontalo", el Harakah (Vol.14 No. 2 Tahun 2012), h. 295.

${ }^{15}$ Moh. Karmin Baruadi, "Sendi Adat dan Eksistensi Sastra, h. 295.

${ }^{16}$ S.R. Nur, Beberapa Aspek Hukum Tata Kerajaan pada Masa Pemerintahan Eyato 1673-1679 (Ujung Pandang: UNHAS Press, 1979), h. 220.

${ }^{17}$ Ibrahim, Proses Masuk dan Berkembangnya Agama Islam di Gorontalo (Gorontalo: STKIP, 2004), h. 57.
} 
Sultan Amai ia mengajukan beberapa persyaratan Islami dalam pelaksanaan pernikahannya dengan Amai, yaitu (1) Sultan Amai dan rakyat Gorontalo harus diislamkan; (2) adat kebiasaan dalam masyarakat Gorontalo harus bersumber dari Alquran (kitabullah).

Dua syarat itu diterima oleh Amai dan beliau sanggup menjadikan masyarakat Gorontalo yang islami. Dalam rumusan Amai dan implementasinya tampak dua sifat yang arif yaitu (a) one side thinking, pemikiran sepihak yang bertitik tolak dari syarat untuk memahami adat yang berlaku; (b) pemikiran yang menghasilkan versi Islam yang diadatkan dan versi inilah yang menjadi dasar pelaksanaan adat sehingga dirasakan oleh masyarakat yang merasakan bahwa tidak ada pertentangan antara adat dengan Islam, malah adat memperkuat dan membimbing pelaksanaannya.

Matolodula Kiki sebagai sultan kedua yang menggantikan ayahnya Amai pada tahun 1550 meneruskan konsep yang dicetuskan oleh ayahandanya. Dalam pengembangan budaya dan peradaban Islam beliau menyempurnakan konsep Amai, dan menelorkan rumusan 'adati hula-hula'a to sara'a dan sara'a hula-hula'a to adati' atau adat bersendi syarak, syarak bersendi adat. Dalam pelaksanaannya tampak dua sifat arif mengikuti ayahnya, yaitu (a) pemikiran yang bersifat reciprocal thinking, berpikir timbal balik, adat dengan syarak, syarak dengan adat; (b) melengkapi versi Islam yang diadatkan dengan versi adat yang diislamkan. ${ }^{18}$ Versi adat yang diislamkan merupakan pemikiran Matolodula Kiki tentang budaya lokal yang berpengaruh terhadap budaya Islam atau adat yang diislamkan.

Konsepsi sendi-sendi keislaman berdasarkan slogan adat bersendi syarak, syarak bersendi kitabullah termanifestasi secara tetap dan dipakai sebagai pedoman hidup adalah pada masa pemerintahan Sultan Eyato, yang pada masa pemerintahannya persatuan u duluwo limo lo Pohalaqa (persekutuan kerajaan di bawah dua kerajaan Gorontalo dan Limboto) agama Islam resmi menjadi agama kerajaan. Rumusan ini mengadung dua sifat yaitu (a) pemikiran yang bersifat linier thinking, istiqomah, lurus, dari adat ke syarak langsung ke kitabullah sebagai landasan tauhid; (b) versi budaya dan peradaban Islam, langsung mengarah kepada versi Islam yang kafah, menyeluruh sesuai surat dalam Alquran:

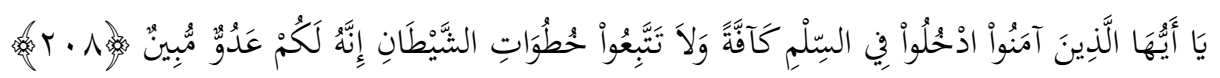

Terjemahnya:

"Hai orang-orang beriman, masuklah kamu ke dalam Islam secara menyeluruh"

(QS al Baqarah/2: 208).

Pada masa pemerintahannya sultan Eyato mengadakan beberapa perubahan Islami dalam sistem pemerintahanya yang didasarkan pada ilmu akidah atau pokokpokok keyakinan dalam ajaran Islam. Dalam ilmu akidah tersebut diajarkan dua puluh sifat Allah SWT. Dalam sistem pemerintahannya, Eyato mewajibkan sifat-sifat itu menjadi sifat dan sikap semua aparat kerajaan mulai dari pejabat tertinggi sampai dengan dengan jabatan terendah. ${ }^{19}$ Dua puluh sifat tersebut adalah sebagai berikut: a) Sifat mukhālafatu lil hawādis, berlainan dengan makhluk. Sifat ini dibajukan kepada sultan sehingga ia berhak untuk memperoleh kehormatan dan wajib menjaga

\footnotetext{
${ }^{18}$ Ibrahim, Proses Masuk dan Berkembangnya Agama Islam di Gorontalo, h. 67.

${ }^{19}$ S.R. Nur, Beberapa Aspek Hukum Tata Kerajaan pada Masa Pemerintahan Eyato 1673-1679, h. 104 .
} 
kehormatannya; b) Sifat kalam, mutakallimun, dibajukan kepada Bantayo Poboide (Dewan Permusyawaratan) yang bertugas mengatur segala sesuatu yang berkaitan dengan kepentingan rakyat dan kerajaan; c) Sifat baqā, kekal, dibajukan kepada kadi, mufti dan imam yang melaksanakan hukum dengan sebagaimana mestinya; d) Sifat qiyāmuhu binafsihi, berdiri di atas pendapat sendiri, dibajukan kepada tokoh adat Baate dan Wu'u yang diharapkan mereka memiliki pendapat sendiri; e) Sifat sama dan basara, mendengar dan melihat, dibajukan kepada para kepala kampung (wala'apulu), sebagai penyambung lidah rakyat, mendengar dan melihat dari rakyat dan diteruskan kepada pejabat di atasnya, demikian pula sebaliknya.

Sendi-sendi yang telah diuraikan sebelumnya sangat mempengaruhi seluruh aspek kehidupan masyarakat Gorontalo, termasuk di antaranya adalah kegiatan bersastra. Pola kebudayaan "Adat bersendikan syarak, dan syarak bersendikan kitabullah (Alquran)", dalam bidang sastra pengaruhnya sangat terlihat terutama pada nuansa hukumnya, baik dalam bentuk maupun isinya. Ada bentuk-bentuk ucapan yang diungkapkan langsung, ada pula yang harus dibacakan dengan lagu pada upacara tertentu. Apabila dilihat dari segi isinya, selain ada yang memang secara langsung mengandung ajaran syariat, ada pula yang secara tidak lansung memberikan gambaran perilaku dan kehidupan sehari-hari berdasarkan syariat Islam. ${ }^{20}$ Kisah-kisah (cerita) dari Alquran atau dari Nabi Muhammad, banyak ditemukan menghiasi isi puisi dan cerita rakyat. Para sastrawan menggunakan kisah sebagai alat untuk mengeksploatasi bentuk-bentuk karya sastra. $^{21}$

Kegiatan berbudaya di Gorontalo pada umumnya sangat kental dengan agama Islam. Hal ini berkaitan erat dengan slogan "aadati hula-hula'a to sara'a, sara'a hulahula'a to kuru'ani" atau adat bersendikan syarak dan syarak bersendikan Alquran (kitabullah). Oleh karenanya setiap peringatan hari besar Islam, kesatuan adat, budaya dan agama dapat terlihat jelas.

\section{METODOLOGI PENELITIAN}

Jenis penelitian adalah deskriptif kualitatif dengan jenis studi kasus yang lebih menekankan pada grounded research. Penelitian ini dilakukan di Gorontalo, dan difokuskan pada adat-istiadat yang masih berlaku di Gorontalo. Adapun pendekatan yang digunakan dalam penelitian ini adalah pendekatan fenomenologi, etnografi, sosioedukatif, dan hukum Islam.

Sumber data penelitian ini diperoleh dari data primer dan data sekunder. Adapun data primer penelitian ini diperoleh dari individu-individu yang berkompeten dalam hal tradisi dan adat-istiadat masyarakat Gorontalo baik dari lingkungan akademisi, budayawan, tokoh adat, tokoh agama, maupun tokoh masyarakat lainnya yang masih terlibat aktif dalam berbagai pelaksanaan ritus budaya di Gorontalo. Untuk melengkapi data primer dan sekunder tersebut, penelitian ini juga menggunakan dokumen berupa buku dan hasil penelitian yang relevan serta arsip-arsip yang terkait dengan sejarah Gorontalo dan Islamisasinya. Teknik pengumpulan data dalam penelitian ini dilakukan dengan tiga cara, yaitu: (1) observasi partisipasi (participant observation); (2) wawancara mendalam (in depth interview); dan (3) penggunaan dokumen (document used). Penelitian ini menggunakan 3 (tiga) instrumen utama yaitu: peneliti sendiri (human instrument); pedoman observasi; dan pedoman wawancara.

\footnotetext{
${ }^{20}$ Nani Tuloli, Sastra dan Ilmu Sastra (Bandung: Pustaka Jaya, 1994), h. 78.

${ }^{21}$ Nani Tuloli, Sastra dan Ilmu Sastra, h. 83.
} 
Analisa data dalam penelitian ini bersifat deskriptif (deskriptif analitis), bukan uji hipotesis. Selain itu, analisis data yang juga urgen untuk digunakan dalam penelitian ini adalah analisis komparatif. Analisis data penelitian ini dilaksanakan bersamaan waktunya dengan tahap pengumpulan data di lapangan, bahkan analisis data dilakukan sejak awal dan sepanjang proses penelitian berlangsung. Untuk menarik kesimpulan, data yang dihimpun diolah melalui proses reduksi, sajian data, dan verifikasi.

\section{HASIL PENELITIAN DAN PEMBAHASAN}

\section{Nilai-Nilai Pendidikan Islam dalam Tradisi Pernikahan (Moponika/Lenggota lo Pohutu)}

Adat pernikahan suku Gorontalo merupakan bagian dari hukum Gorontalo secara keseluruhan dan mempunyai item-item yang berhubungan dengan makna, proses pengiring, perlengkapan adat berupa benda-benda budaya atau atribut adat. Tradisi perkawinan menurut adat di Gorontalo merupakan tradisi yang memiliki prosesi cukup panjang.

Pernikahan menurut hukum adat bisa saja berbeda di setiap daerah di Indonesia, khususnya di Kota Gorontalo dikenal tata ucapara adat pernikahan (pohutu moponika). Upacara adat ini dianggap suci dan agung yang mempunyai beberapa tahapan-tahapan (lenggota lo nika) yang dilalui sebelum, saat dan sesudah acara pokok (akad nikah). ${ }^{22}$

Pada masyarakat Gorontalo terdapat 21 tahapan yang akan dilalui sebelum akad dan resepsi pernikahan, yaitu: (1) mongilalo (meninjau); (2) mohabari (meminta berita); (3) momatata'u pilo'otaawa (meminta ketegasan); (4) motolobalango (menghubungkan/meminang secara resmi proses perkawinan); (5) monga'ato dalalo (meratakan jalan); (6) molenilo (menghubungkan keluarga laki-laki dengan keluarga perempuan); (7) momu'o ngango/modutu (meminta restu dari keluarga dan disaksikan oleh pemerintah dan petugas agama); (8) modepita maharu/tonelo (mengantar mahar); (9) modepita dilonggato (mengantar perangkat penyempurnaan lauk pauk); (10) mopotilantahu (mempertunangkan); (11) mohatamu Qur'ani (khatam Qur'an); (12) motidi (tarian); (13) mopotuluhu (mengistirahatkan); (14) moponika (pra akad nikah); (15) mongakaji (akad nikah); (16) molomela taluhu tabiya (membatalkan air wudu); (17) mopopipidu (menyandingkan); (18) palebohu (nasehat); (19) modelo (membawa pengantin); (20) mopoturunani (acara malam); dan (21) mopotamelo (menyuguhkan makanan). ${ }^{23}$ Rentetan prosesi tersebut diuraikan sebagai berikut:

\section{a. Mongilalo (Peninjauan)}

Prosesi ini bertujuan untuk memperjelas calon pasangan yang akan dinikahi. Persiapan pada acara ini belum menggunakan atribut adat atau benda budaya. Dari segi busana, laki-laki mengenakan bo'o kini (krag cina), celana batik, kopiah keranjang yang diistilahkan bo'o lo mongo tiyamo. Sedangkan yang perempuan mengenakan kebaya, bide-bide lo lipa-lipa (sarung sebagai rok), wulo-wuloto lo bate (kain penut up dari batik) dan memakai konde. Hal lain yang juga disiapkan adalah imbalan jasa atau

\footnotetext{
${ }^{22}$ Mansyur Pateda, et. al (eds.), Pohutu Aadati Lo Hulondalo: Tata Upacara Adat Gorontalo (Hasil Seminar Adat Gorontalo, 2017) (Gorontalo: Pemda Kabupaten Gorontalo Kerjasama Forum Pengkajian Islam Al-Kautsar Gorontalo, 2008), h. 147-148.

${ }^{23}$ Ajub Ishak, Hukum Perdata Islam di Indonesia dan Prakek Perkawinan dalam Bingkai Adat Gorontalo (Cet. 1; Gorontalo: Sultan Amai Press, 2014), h. 88-98.
} 
sedekah seikhlasnya dari orang tua laki-laki yang diberikan kepada utusan yang akan berangkat untuk mongilalo ke rumah calon istri anaknya. ${ }^{24}$

Adapun rangkaian pelaksanaannya antara lain yaitu:

1) Orang tua pihak laki-laki terlebih dahulu menanyakan langsung ketetapan hati anaknya untuk memilih calon istri. Orang tua juga menawarkan calon-calon mereka namun yang memutuskan adalah anaknya sendiri.

2) Bagi calon istri yang sudah dijodohkan sejak kecil (huhuwo) maka tetap diadakan mongilalo, tetapi yang diutus adalah utusan yang tidak biasa dilihat mereka (keluarga calon istri).

3) Kedatangan utusan ini ditetapkan sore hari pukul 16.00 atau di waktu Asar tanpa pemberitahuan dahulu.

4) Waktu bertamu hanya satu jam kecuali jika mereka terlibat pada pembicaraan yang serius, namun sebelum Magrib sudah kembali. Hasil peninjauan diceritakan seutuhnya, tanpa ditambah dan dikurangi untuk dijadikan bahan pertimbangan mereka dengan calon suami. Apabila sepakat maka akan dilanjutkan ke tahap berikutnya. $^{25}$

\section{b. Mohabari}

Adat mohabari merupakan tahapan pranikah yang bertujuan untuk memperjelas kepada keluarga calon istri akan adanya pernikahan. Dalam prosesi mohabari, atribut adat atau benda budaya sudah mulai digunakan, antara lain berupa:

1) Sirih, pinang, kapur, gambir, dan tembakau, yang dibungkus dengan kain dua macam (warna), yaitu merah muda dan ungu.

2) Sebuah tapahula (kotak kayu berbentuk bundar dan memakai penutup) yang berisi uang 10 kati atau Rp. 10.000,-.

Terdapat pula ketentuan dalam hal busana adat, yaitu:

1) Laki-laki memakai setelan bo'o kini, kopiah, sedangkan perempuan memakai kebaya, bide bate, wulo-wulota lipa-lipa (payu lo hulantalo). Adapun kebaya, bide kipa-lipa, wulo-wulota bate (untuk payu lo limutu). Busana ini adalah busana dari orang tua laki-laki sebagai utusan anaknya.

2) Busana adat yang menyambut atau orang tua perempuan, untuk laki-laki memakai celana panjang, kemeja lengan panjang, kopiah. Sedangkan ibu/perempuan memakai kebaya, bide, dan wuloto. ${ }^{26}$

Adapun prosesi pelaksanaannya meliputi beberapa rangkaian berikut:

1) Kedatangan orang tua laki-laki ini secara rahasia, tanpa pemberitahuan atau kunjungan tidak resmi. Kedatangan mereka dengan membawa benda-benda budaya sebagaimana telah disebutkan, tersembunyi di balik wuloto (kain penutup). Kunjungan ini dilakukan pada sore hari, setelah Asar. Agar perjalanan tidak sia-sia, secara diam-diam terlebih dahulu diutus seseorang yang melihat dari jauh untuk memastikan apakah kedua orang tua perempuan berada di rumah atau tidak. Jika keduanya berada di rumah, barulah mereka bertamu ke rumah tersebut.

2) Setelah tiba di rumah calon perempuan. Sirih pinang dalam pomama (tempat sirih pinang) dan tapahula diletakkan di depan mereka untuk sama-sama dinikmati sebagai suguhan.

\footnotetext{
${ }^{24}$ Medi Botutihe dan Farhah Daulima, Tata Upacara Adat Gorontalo (t.tp, 2003), h. 101.

${ }^{25}$ Medi Botutihe dan Farhah Daulima, Tata Upacara Adat Gorontalo, h. 103.

${ }^{26}$ Farhah Daulima, Tata Cara Adat Perwakinan pada Masyarakat Adat Suku Gorontalo (Gorontalo: LSM Mbu'i Bungale, 2006), h. 11.
} 
3) Setelah selesai memakan sirih pinang, maka orang tua laki-laki menyampaikan maksud kedatangan mereka dengan diawali kalimat basa-basi. Pada umumnya pembicaraan tersebut dilakukan dengan menggunakan pantun atau peribahasa atau saling berbalas pantun. Jawaban dari pihak keluarga perempuan biasanya menghendaki agar mereka diberikan kesempatan untuk memusyawarahkan hal tersebut dengan keluarga besar mereka.

4) Berdasarkan jawaban tersebut maka pihak orang tua laki-laki memohon diri dan berjanji untuk kembali lagi. ${ }^{27}$

\section{c. Momatata u pilo'otowa (meminta ketegasan)}

Pelaksana pada prosesi momatata u pilo'otowa ini antara lain adalah.: ${ }^{28}$

1) Ti Utoliya, yaitu orang yang ditunjuk sebagai penghubung oleh pihak keluarga laki-laki dengan persyaratan sebagai berikut:

a) Laki-laki berumur separuh baya.

b) Jujur dan berwibawa.

c) Beragama Islam.

d) Berpengalaman dalam berbahasa adat dan pelaksanaan adat.

2) Dua orang laki-laki dari pihak keluarga laki-laki yang menemani Utoliya. Kedua orang tersebut disertakan sebagai saksi dan yang berperan adalah Ti Utoliya.

Beberapa hal yang perlu dipersiapkan dalam prosesi momatata u pilo'otowa ini adalah:

1) Atribut adat atau benda budaya yang meliputi:

a) Selembar kain sejenis sutra yang indah polos atau bercorak kembang.

b) Tapahula yang berisi kain tersebut pada poin a).

c) Tonggu bernilai Rp. 25,- yang saat ini senilai dengan Rp. 1.600,-

2) Busana adat:

a) Utoliya, mengenakan busana adat takowa kiki, kopiah, sarung dililitkan pada pinggang di luar baju.

b) Dua orang saksi mengenakan kemeja lengan panjang, celana panjang berlilitkan sarung di luar baju/kemeja dan memakai kopiah.

Adapun rangkaian prosesi atau pelaksanaannya yaitu:

1) Tiga hari setelah prosesi mohabari, maka diutuslah oleh pihak keluarga laki-laki $T i$ Utoliya untuk mendapatkan ketegasan sebagai jawaban dari pihak keluarga perempuan. Ti Utoliya ini datang dengan membawa tapahula yang berisi selembar kain sejenis sutra dan tonggu.

2) Di rumah keluarga pihak perempuan, tamu kehormatan ini diterima dan dijamu dengan berbagai hidangan/minuman.

3) Setelah acara umum, Ti Utoliya menyodorkan tonggu yang disambut dan dibuka oleh orang tua perempuan. Ti Utoliya kemudian dipersilahkan untuk memulai pembicaraan. Setiap dialog antara kedua belah pihak menyertakan simbol-simbol adat berdasarkan benda budaya yang dibawa serta yang masing-masing memiliki makna tersendiri. Jadi pada intinya, meskipun bersifat informal tetapi prosesi ini sudah mengikat berdasarkan musyawarah masing-masing keluarga. Kesuksesan prosesi ini sekaligus menjadi jalan bagi keberlanjutan pada tahapan berikutnya.

d. Motolobalango (peresmian hasil pembicaraan) ${ }^{29}$

\footnotetext{
${ }^{27}$ Farhah Daulima, Ragam Upacara Adat Gorontalo (Limboto: Forum Suara Perempuan MBUI Bungale, 2006), h. 30.

${ }^{28}$ Farhah Daulima, Ragam Upacara Adat Gorontalo, h. 15-19.
} 
Prosesi motolobalango merupakan acara peresmian hasil pembicaraan dari ketiga tahapan sebelumnya di lingkungan keluarga kedua belah pihak. Pada prosesi ini juga belum melibatkan pemerintah, pegawai syarak, maupun bunyi-bunyian. Dengan demikian, prosesi masih bersifat saling merestui antar keluarga kedua belah pihak, belum ada tawar menawar ongkos dan teknik pelaksanaan perkawinan sebab hal tersebut sudah jelas pada tahap sebelumnya. Adapun pelaksana pada prosesi motolobalango ini adalah:

1) Luntu Dulungo Layi'o atau juru bicara dari pihak laki-laki yang disebut Utoliya sebagaimana yang telah ditunjuk oleh pihak keluarga laki-laki.

2) Luntu Dulungo Wolato atau juru bicara dari pihak perempuan yang juga telah ditunjuk oleh pihak keluarga perempuan.

3) Peserta yang mendampingi Luntu Dulungo Layi'o terdiri dari keluarga pihak lakilaki (laki-laki dan perempuan).

4) Peserta yang menunggu duduk bersama Luntu Dulungo Wolato terdiri keluarga dari pihak perempuan.

5) Pembawa hantaran adat yang masing-masing membawa sirih pinang, baki berisi gambir, tembakau, dan kapur, baki tapahula yang berisi kain sejenis sutra, serta payung tertutup.

Adapun persiapan atribut adat atau benda budaya yang akan digunakan antara lain adalah:

1) Sirih, pinang, gambir, kapur, dan tembakau.

2) Tapahula yang berisi kain sejenis sutra dengan panjang tiga meter.

3) Toyunga bilalanga atau payung kebesaran adat.

Disamping benda budaya tersebut terdapat pula ketentuan dalam busana yang harus dikenakan, yaitu:

1) Untuk gadis calon pengantin, busana adat yang dikenakan adalah walimomo, to huwali lo humbiyo (kamar adat), dan duduk di ranjang berkelambu adat.

2) Untuk Luntu Dulungo Layi'o maupun Dulungo Wolato adalah bo'o takawa kiki, sarung terikat di pinggang, dan memakai kopiah hitam.

3) Busana yang dikenakan oleh kaum bapak pada umumnya berlengan panjang, celana panjang, dan kopiah. Sedangkan kaum ibu mengenakan kebaya dan batik, kain penutup (wuloto). Ketentuan ini juga berlaku kepada pihak keluarga perempuan.

Setelah atribut adat dan busana adat disiapkan, maka dilanjutkan dengan prosesi dengan rangkaian sebagai berikut:

1) Pelaksanaan secara adat motolobolango selalu diadakan pada sore hari mulai pukul 15.00 sampai selesai. Rombongan meninggalkan rumah keluarga laki-laki dipimpin oleh Luntu Dulungo Layi'o atau Utoliya menuju rumah keluarga perempuan dengan membawa benda-benda budaya di atas baki yang telah disiapkan.

2) Rombongan diterima oleh pihak keluarga perempuan. Kedua belah pihak duduk beralaskan tikar atau permadani dengan berhadap-hadapan. Tonggu disodorkan, kemudian disusul dengan baki-baki lainnya. Pada saat tonggu dibuka maka dimulailah dialog atau musyawarah yang pada umumnya menggunakan bahasa daerah berpantun.

3) Setelah dialog selesai, diakhiri dengan saling berjabat tangan seluruh rombongan kedua belah pihak. Selanjutnya acara makan-minum bersama. Kemudian Utoliya

\footnotetext{
${ }^{29}$ Farhah Daulima, Ragam Upacara Adat Gorontalo, h. 26-57.
} 
mengumumkan/memaklumkan hari dan tanggal untuk melanjutkan tahap proses perkawinan, yakni tahap monga'ato datalo (meratakan jalan/proses).

\section{e. Monga'ato dalalo (meratakan jalan)}

Monga'ato dalalo merupakan prosesi memuluskan jalannya proses perkawinan. Dalam prosesi ini, yang dibicarakan adalah kelanjutan dari kesepakatan-kesepakatan sebelumnya yang telah dibahas secara global dan belum terurai secara rinci. Hal ini dilakukan untuk menghindari kesalahpahaman. Misalnya, pu'ade (tempat pelaminan) dan pakaian pengantin yang bagaimana yang disukai oleh pihak perempuan. Kemungkinan lainnya adalah jika pihak perempuan yang meminjam pu'ade dan pakaian pengantin dan pihak laki-laki yang membayarnya, atau pihak laki-laki yang mengadakannya/menyiapkannya, sedangkan pihak perempuan cukup menerima saja, atau kesepakatan-kesepakatan teknis lainnya. Jadi pada intinya prosesi ini adalah memusyawarahkan kembali teknis pelaksanaan proses perkawinan secara rinci, jelas, dan terarah, agar pelaksanaannya nanti dapat mulus, lancar, dan tertib. Sedapat mungkin diupayakan tidak akan ada lagi kesalahpahaman yang dapat memicu ketersinggungan.

Dalam pelaksanaannya, prosesi monga'ato dalalo ini membahas beberapa teknis seperti:

1) Biaya pesta perkawinan; persiapan beras, dan jumlah sapi.

2) Biaya busana pengantin; pu'ade (tempat pelaminan), busana adat pengantin dengan tiga kali ganti busana, yakni pada saat di pelaminan, resepsi, dan pada saat dibawa ke rumah laki-laki.

3) Biaya bunyi-bunyian (musik), dan dokumentasi.

4) Perlengkapan tenda, undangan, penambahan daya listrik.

5) Biaya adat; sedekah kepada perangkat adat, acara mopotilantahu (kesenian tidi, molapi saronde, dan mohatamu), serta acara modelo.

Dalam acara ini pula kemungkinan kesepakatannya adalah bahwa biaya ditanggung bersama atau dibagi-bagi apa yang akan ditanggung oleh masing-masing pihak. Setelah memperoleh mufakat, acara ditutup dengan makan-minum bersama dan rombongan pulang dan akan kembali tiga hari kemudian untuk acara molinelo.

\section{f. Molenilo (membawa hantaran khusus) ${ }^{31}$}

Molenilo berasal dari kata tenilo yaitu alat yang digunakan untuk mengalirkan atau menampung air pada sambungan rumah. Tenilo juga diartikan sebagai alat penghubung antara bagian rumah dengan bagian yang lain. Molenilo berarti menampung atau mengalirkan air dari dua atap bagian rumah. Dengan demikian, hakikat molenilo adalah menghubungkan antara kedua keluarga, bukan saja secara lahiriah tetapi secara batiniah menjadi keluarga atau kerabat. Hubungan ini diwujudkan dengan hantaran khusus untuk calon pengantin perempuan berupa seperangkat pakaian yang terbagus dari calon suaminya.

Pelaksanaan prosesi molenilo ini memiliki rangkaian sebagai berikut:

1) Acara didahului dengan pemberitahuan tentang kedatangan rombongan yang akan melaksanakan acara adat molenilo. Rombongan tetap dipimpin oleh Utoliya tanpa bunyi-bunyian.

2) Ketika tiba di rumah pihak perempuan, rombongan dipersilahkan duduk di atas tikar atau permadani. Tonggu disodorkan, baki yang berisi sirih, pinang, dan lain-

\footnotetext{
${ }^{30}$ Farhah Daulima, Ragam Upacara Adat Gorontalo, h. 59-65.

${ }^{31}$ Farhah Daulima, Ragam Upacara Adat Gorontalo, h. 67-72.
} 
lain, tapahula berisi tilomungo untuk calon pengantin perempuan diletakkan di atas kain merah muda yang dialaskan di depan Utoliya.

3) Setelah itu Utoliya Luntu Dulungo Layi'omembuka pembicaraan, dimulai dengan memaparkan maksud kedatangannya dan menjelaskan apa yang dibawanya untuk calon pengantin perempuan dari calon suaminya.

4) Pembicaraan dilanjutkan dengan penetapan waktu untuk adat momu'o ngango atau modutu yang akan dihadiri oleh pihak keluarga, pemerintah, dan pegawai syarak.

5) Dalam pembicaraan tersebut dibahas pula tempat untuk pelaksanaan acara modutu. Mengundang pemerintah setempat, pegawai syarak, buwatulo to wulungo adalah hak dari pihak keluarga perempuan. Sedangkan sedekah bagi pelaksana adat dan untuk buwatulo to wulungo merupakan hak dari keluarga pihak laki-laki.

6) Setelah pembicaraan dan penyampaian tilomungo selesai maka rombongan kembali pulang untuk mempersiapkan tahapan berikutnya (momu'o ngango).

g. Momu'o Ngango/Modutu (pengukuhan teknis acara) ${ }^{32}$

Acara momu'o ngango/modutu merupakan pembahasan terakhir menyangkut teknis pelaksanaan pada hari perkawinan. Acara ini sekaligus merupakan pengukuhan keluarga dan disaksikan oleh pemerintah setempat dan pegawai syarak serta seluruh kerabat dan tetangga.

Adapun persiapan pada prosesi ini meliputi beberapa benda-benda budaya sebagai berikut:

1) Kola-kola, yaitu sebuah usungan terbuat dari bambu kuning (talila hulawa), berbentuk persegi panjang dan dihiasi dengan janur (lale).

2) Kendaraan.

3) Genderang hantalo.

4) Empat baki limu bongo (jeruk kelapa atau limau yang besar-besar). Setiap baki terdapat empat jenis buah; empat baki nanas, setiap baki empat buah; empat baki nangka, setiap baki satu buah; empat baki tebu, setiap baki terdiri dari tebu biasa (patodu lumbi), tebu kuning, dan tebu darah babi; empat baki tumula (bibit kelapa), setiap baki empat biji.

5) Tonggu senilai Rp. 25,- yang sekaran senilai dengan Rp. 1.600,- yang diisi pada sebuah pomama (tempat pinang) perak dan ditutup dengan penutup tonggu ( $t a{ }^{\prime} a b u$ tonggu), yang berbentuk segi tiga (tutuliyo totolu).

Prosesi momu'o ngango/modutu meliputi beberapa rangkaian pelaksanaan sebagai berikut:

1) Rombongan kola-kola dari pihak keluarga laki-laki tutun 25 meter dari pintu masuk rumah orang tua perempuan atau rumah tempat menunggu untuk pelaksanaan acara tersebut. Penghubung (Balanga) memberitahukan kepada keluarga pihak perempuan bahwa perangkat hu'o lo ngango telah tiba.

2) Dengan dipimpin oleh Utoliya Luntu Dulungo Layi'o, maka rombongan berjalan perlahan-lahan disertai oleh para pembawa baki dengan urutan baki sirih pinang di depan dan buah-buahan di belakang, berbanjar empat-empat dengan iringan hantalo.

3) Utoliya Wolato telah menunggu di pintu masuk, maka terjadilah dialog penyambutan yang dimulai oleh Utoliya Luntu Dulungo Layi'o dengan tuja'i yang dijawab oleh Utoliya Wolato dengan sambutan tuja'i pula.

\footnotetext{
${ }^{32}$ Farhah Daulima, Ragam Upacara Adat Gorontalo, h. 73-87.
} 
4) Setelah saling berbalas tuja'i maka selanjutnya Luntu Dulungo Wolato membagibagikan secara teratur sebagai berikut:

a) Nangka dan tebu kuning untuk pemerintah setempat.

b) Tebu merah untuk pemangku.

c) Tebu hijau untuk anak-anak.

d) Limau dan nenas untuk para pejabat.

e) Tumula (bibit kelapa) untuk kedua calon pengantin.

f) Sirih, pinang, gambir, tembakau, dan kapur untuk para tamu lainnya yang diundang.

5) Setelah membagi-bagi hu'o lo ngango maka dilanjutkan dengan makan dan minum bersama yang dilanjutkan dengan pengumuman oleh Utoliya Luntu Dulungo Layi'o tentang tujuh hari pelaksanaan acara adat modepita maharu atau tonelo.

6) Sejak tahap motolobalango selesai, mulailah diadakan persiapan yang berhubungan dengan hal-hal lahiriah dan batiniah bagi calon pengantin perempuan. Calon pengantin perempuan pun telah ditempatkan di kamar khusus yang disebut huwali lo wadaka atau kamar bersolek dan mulai dibekali dengan pelatihan-pelatihan pranikah, khatam Alquran, dan bekal agama lainnya. Proses tersebut dijalani oleh calon pengantin perempuan selama 40 hari. Sebelum memasuki kamar khusus ( huwali lo wadaka), calon pengantin perempuan terlebih dahulu dimandikan dengan talluhu yilonuwa (air kembang) dari tujuh buah bambu kuning oleh salah seorang tokoh adat.

Setelah acara momu'o ngango/modutu, acara selanjutnya adalah prosesi penyerahan mahar (modepita maharu). Mahar dan benda-benda budaya lainnya diantarkan dengan dengan prosesi khusus sebagaimana prosesi yang lainnya. Pada prosesi ini juga dilakukan penetapan hari penyerahan rempah-rempah (dilonggato) atau perlengkapan dapur.

Prosesi selanjutnya adalah acara adat modepita dilonggato atau acara pengantaran bahan-bahan penyempurnaan seperangkat makanan untuk hari pelaksanaan perkawinan. Termasuk dalam dilonggato adalah seekor sapi, sekarung beras, kambing, ayam, dan sebagainya. Meskipun hal ini merupakan kewajiban dari pihak laki-laki, namun tidak menutup kemungkinan disempurnakan pula oleh pihak perempuan.

Setelah acara modepita dilonggato, dilanjutkan dengan acara inti dari semua prosesi yang telah ada sebelumnya, yaitu acara moponika. Dalam acara moponika ini terdapat beberapa rangkaian kegiatan sebagai berikut:

1) Mopotilandahu (mempertunangkan) dan molapi saronde (menari saronde).

2) Mohatamu (khatam Alqur'an).

3) Mopotidi (tarian tidi).

4) Mopotoluhu (pengantin laki-laki diistirahatkan di kamar pengantin).

5) Mongakaji (akad nikah).

6) Molomela taluhu tabiya (membatalkan air wudu).

7) Mopipidu (menyandingkan).

8) Momale bohu (memberikan nasihat perkawinan).

9) Modelo (mengantar pengantin perempuan ke rumah pengantin laki-laki).

10) Mopoturunani (kedatangan kedua orang tua laki-laki ke rumah pengantin perempuan untuk memastikan keperawanan menantunya). 
11) Mopotomelo (menyuguhkan makanan kepada kedua mempelai setelah melewati malam pertama).

Keseluruhan prosesi ini ditutup dengan penyerahan mahar oleh ibu pengantin perempuan kepada kedua sebagai pertanda penyerahan modal untuk hidup dan burusaha mencari rezeki bagi keduanya.

Pada tradisi pernikahan terdapat nilai pendidikan moral yang sangat urgen. Diawali dari proses khitbah (lamaran), Pelaksana khitbah (pertunangan) berjalan sesuai dengan pola adat, pakaiannya, gerak-geriknya, bahasanya serta kelengkapan adat yang dibutuhkannya. Hal ini mengandung makna sumber dari nilai pernikahan kedua calon mempelai yang masih berstatus murni dan suci serta ketulusan moral dari kedua calon pengantin tersebut. Selanjutnya ucapan-ucapan dalam pertunangan itu diawali dengan proses adat disebut (a) tahap mongaato dalalo, proses meratakan jalan pembicaraan dilengkapi dengan simbol adat, sirih, pinang, tembakau, gembir dan kapur; dilanjutkan dengan (b) tahap moтu'o ngango, memulai pembicaraan, dilengkapi dengan simbolsimbol adat yang ada, ditambah dengan adat tonggu (sejumlah uang perak) pembayaran adat kepada orang tua pihak keluarga perempuan, sehingga pihak laki-laki sudah leluasa berbicara dengan pihak keluarga perempuan. Makna tahapan adat ini adalah bahwa adat meratakan jalan dan adat membuka suara pertama, menggambarkan apa yang dibicarakan itu masih berada pada kondisi kumuliaan yang asli, dan kehormatan yang masih murni belum pernah terbuka rahasianya. Kondisi ini adalah milik kedua calon pengantin yang dibicarakan dalam adat peminangan ini. ${ }^{33}$

Pada malam hari pernikahan, di rumah pengantin perempuan ada dua acara yang akan dilangsungkan yaitu khatam Alquran dan Motidi lo Polopalo. Kedua acara ini dilaksanakan sendiri oleh calon pengantin perempuan, setelah acara makan malam dia membacakan beberapa surah pada Juz yang ketiga puluh dari kitab suci Alquran. Sebelumnya dia sudah berpakaian adat dan berada di kamar adat. Dia akan dijemput oleh tokoh adat dengan penyampaian tuja' $i$ antara lain sebagai berikut: ${ }^{34}$

Mbui hulawa tuluto (Tuan putri yang mulia)

Yinggato poliyodupo (Mohon melangkah)

Layi'o pongoabupo... (Kembangkan sayapmu)

Setelah itu, pengantin langsung dibimbing ke tempat adat pelaksanaan khatam Alquran yang disebut puade. Di atas puade itulah pengantin duduk membacakan ayat-ayat suci Alquran kurang lebih satu jam lamanya. Makna pelaksanaan adat ini adalah gambaran manusia yang mulia karena moralnya dan makna khatam Alquran adalah bahwa setiap perempuan yang siap kawin sudah harus lancar membaca dan memahami isi Alquran sebagai pedoman hidup berumah tangga, dan paling utama bahwa dia telah memiliki dasar moral yang Islami. Pengantin laiki-laki pun wajib mengkhatam Alquran. Pelaksanaannya pada pesta di siang hari, adat menyambutnya, khatamu lo ta lolai, khatam laki-laki. ${ }^{35}$

Selanjutnya acara tidi lo polopalo, pengantin dijemput lagi dengan sanjak tuja' $i$ jemputan berikut ini:

Mbui lo hunggi-hunggia (Tuan putri yang mulia)

Malo puduo botiya (Putri akan dipersilakan)

Pintu malo huolo (Pintu akan diangkat)

Wahu maponggetalo (Segera bergerak)

\footnotetext{
${ }^{33}$ Moh. Karmin Baruadi, "Sendi Adat dan Eksistensi Sastra; Pengaruh Islam dalam Nuansa Budaya Lokal Gorontalo”, el Harakah (Vol. 14 No. 2 Tahun 2017), h. 308.

${ }^{34}$ Moh. Karmin Baruadi, "Sendi Adat dan Eksistensi Sastra, h. 309.

${ }^{35}$ S.R. Nur, Beberapa Aspek Hukum Adat Tata Negara Kerajaan Gorontalo, h. 25.
} 


\section{Malo po potidiyolo, mbui (Silakan menari tuan putri)}

Tidi lo polopalo yang mengandung empat belas macam gerakan, intinya adalah tindakan moral dalam mengendalikan masalah rumah tangga. Misalnya pada gerakan ketiga yang bermakna: dalam menghadapai masalah-masalah yang baik dan menguntungkan, jangan segera ditindaki, harus didahului oleh pertimbangan moral, pikiran, perasaan dan kemauan. ${ }^{36}$

Selanjutnya nilai moral pada versi adat yang di islamkan yang berkaitan dengan komunikasi sosial antara lain tuja'i sebagai berikut.

Opiyohe lo dulelo (Jika perilaku baik)

Openu dila motonelo (Tidak perlu membiayai)

Opiyohe lo moiya (Jika baik tutur kata)

Openu dila doiya (Tidaklah perlu dengan uang)

\section{Nilai-Nilai Pendidikan Islam dalam Tradisi Molontalo(Tujuh Bulanan)}

a. Prosesi Tradisi Molontalo ${ }^{37}$

1) Pelaksana

- Kerabat pihak suami

- Hulango atau bidan kampung, dengan memenuhi beberapa persyaratan: (1) beragama Islam; (2) mengetahui seluk beluk usia kandungan; (3) mengetahui urutan upacara adat molontalo; (4) mengetahui lafal-lafal yang telah diturunkan oleh leluhur dalam pelaksanaan acara tersebut, dan; (5) diakui oleh kelompok masyarakat sebagai bidan kampung. ${ }^{38}$

- Imam atau hatibi, atau yang ditokohkan sebagai pelaksana keagamaan yang mampu dan mahir lafal doa salawat (mo'odelo).

- Dua orang anak perempuan usia 7-9 tahun, keduanya masih lengkap orang tuanya (payu lo limutu), satu orang anak perempuan usia 7-9 tahun (payu lo hulantalo).

- Dua orang ibu dari keluarga sakinah. ${ }^{39}$

2) Persiapan

a) Atribut adat/benda budaya

- Hulante yang berbentuk seperangkat bahan di atas baki, terdiri dari beras dua cupak atau tiga liter, di atasnya terletak tujuh buah pala, tujuh buah cengkeh, tujuh buah telur, tujuh buah limututu (lemon sowanggi), tujuh buah mata uang yang bernilai Rp. 100.-Dahulu mata uang terdiri dari ringgit, rupiah, suku, tali ketip, kelip. ${ }^{40}$

\footnotetext{
${ }^{36}$ Ibrahim Polontalo, Upaya-upaya Pemertahanan Sistim Nilai Adat Bersendikan Syarak, Syarak Bersendikan Kitabullah sebagai Prinsip Adat Gorontalo (Gorontalo: UNG, 2004), h. 32.

${ }^{37}$ Prosesi atau tata cara tradisi molonthalo ini dapat dilihat, Nani Tuloli, dkk., Ragam Upacara Tradisional Daerah Gorontalo (Cet. I; Gorontalo: Sub Dinas Kebudayaan Dinas Pendidikan dan Kebudayaan Provinsi Gorontalo, 2006), h. 1-20.

${ }^{38}$ Hadijah, Oci Toino, dan Saida Karim (Bidan Kampung), Hasil Wawancara, di Gorontalo pada tanggal 14 Juli 2017.

${ }^{39}$ Ningsi Pakaya dan Asmin Usman (Tokoh Pemuda), Hasil Wawancara, di Gorontalo pada tanggal 14 Juli 2017.

${ }^{40}$ Abdul Gias Suluni (Tokoh Adat), Hasil Wawancara, di Gorontalo pada tanggal 14 Juli 2017.
} 
- Seperangkat bahan pembakaran dupa di atas baki, yang terdiri dari sebuah polutube (pedupaan), sebuah baskom tempat tetabu (dupa) dan segelas air masak yang tertut up. ${ }^{41}$

- Seperangkat botu pongi'ila (batu gosok), yaitu batu gosok untuk mengikis kunyit sepenggal, dicampur sedikit kapur, dan air dingin yang disebut alawahu tilihi. ${ }^{42}$

- Seperangkat pomama (tempat sirih, pinang), tambaluda atau hukede.

- Sebuah toyopo atau seperangkat makanan, tempatnya terbuat dari daun kelapa muda (janur) yang berisi nasi kuning, telur rebus, ayam goreng, dan kue-kue dapat wapili, kolombengi, apangi, dan lain-lain, ditambah pisang masak terdiri dari pisang raja atau pisang gapi (lutu tahulumito atau lutu lo hulonti'o). Seperangkat makanan ini akan dibagikan kepada yang berhak, antara lain: 1) toyopo/pala'u lo ta mongadi salawati (diperuntukkan kepada yang membaca doa salawat); 2) pala'u lo hulango (diperuntukkan kepada bidan kampung sebagai pelaksana acara); 3) pala'u to la polontaliyo (diperuntukkan kepada kedua anak yang meletakkan tangannya di atas perut yang di-tontalo pada saat acara molontalo berlangsung -dua pala'u); 4) pala'u lo ta pohiwululaliyo-yang dijadikan bantal (diperuntukkan kepada seorang ibu yang duduk di tempat bagian kepala dari ta tontaloliyo pada saat acara molontalo berlangsung); 5) pala'u lo ta podihu liyo hu'u (diperuntukkan kepada seorang ibu yang memegang kedua lutut pada saat acara molontalo berlangsung); 6) pala'u lo ta podihu liyo lalante bula (diperuntukkan kepada seorang ibu yang berdiri di balik tirai tikar yang terbungkus dengan batik di pintu keluar, yang juga menjawab pertanyaan hatibi/imam pada saat acara molontalo berlangsung. ${ }^{43}$

- Seperangkat makanan di atas baki terdiri dari sepiring bilinti, atau sejenis nasi goreng yang dicampur dengan hati ayam, sepiring ayam goreng yang masih utuh dan di perutnya dimasukkan sebuah telur rebus, dua buah baskom tempat cuci tangan dan dua buah gelas berisi air masak, dan dua buah sendok makan.

- Sebuah daun silar (tiladu) berkepang tiga (tiladu tula-tula pidu), seukuran perut ibu yang hamil.

- Bulewe atau upik pinang (malo ngo'alo).

- Sebuah tempurung tidak bermata (buawu huli). Tempurung ini akan dipecahkan dengan siku oleh suami yang diacarakan.

\footnotetext{
${ }^{41}$ Abdul Gias Suluni dan Saleh Tobuhu (Tokoh Adat), Hasil Wawancara, di Gorontalo pada tanggal 14 Juli 2017.

${ }^{42}$ Abdul Gias Suluni (Tokoh Adat), Hasil Wawancara, pada tanggal 14 Juli 2017 di Gorontalo.

${ }^{43}$ Tujuh martabat yang harus dicapai manusia menurut versi buku Tata Upacara Adat Gorontalo adalah: 1) Latifatul Kalbi; 2) Latifatul Ruh; 3) Latifatul Sirri; 4) Latifatul Ahfa; 5) Latifatul Hafi; 6) Latifatul Nafsu Hatika; dan 7) Latifatul Kullu Jasad. Lihat, Medi Botutihe dan Nani Tuloli, Tata Upacara Adat Gorontalo, h. 6.
} 
- Seperangkat tikar putih (amongo peya-peya atau ti'ohu) yang terbungkus (bolu-bolu), yang terpancang di depan pintu (podepodehu), dimana ada seorang ibu di balik tirai itu meneruskan pertanyaan dari syara' (hatibi atau syarada'a, atau Imam) yang bertugas/diundang membacakan doa, kepada Hulango (bidan). Pertanyaan yang disampaikan adalah ma ngolo hula? artinya, sudah berapa bulan? dan dijawab oleh anak-anak tersebut atas petunjuk hulango.

- Pale yilulo (tilondawu), yaitu beras yang diwarnai dengan warna merah, kuning, hijau, hitam, dan putih.

- Sebilah keris bersarung.

b) Busana adat

- Bagi yang diacarakan (sang ibu hamil) memakai busana walimomo konde pakai sunthi dengan tingkatan; satu tangkai untuk umum, tiga tangkai untuk golongan istri wuleya lo lipu (Camat), lima tangkai untuk golongan istri jogugu (Wakil Bupati/Walikota), dan tujuh tingkatan untuk mbui (istri Raja/Bupati/Walikota).

- Suami (calon ayah) memakai bo'o takowa kiki dan payungo tilabatayila, memakai salempang, dan keris yang terselip di pinggang.

- Dua orang anak perempuan memakai galenggo walimomo, kepalanya memakai baya lo bo'ute, atau hiasan kepala.

- Dua orang ibu yang memakai kebaya dan batik, serta batik surang sebagai penutup atau wulo-wuloto, atau busana lo mango ti'ilo.

c) Imbalan Jasa

Imbalan jasa ini berupa sedekah berdasarkan kerelaan dari sepasuami istri yang diberikan kepada beberapa orang, yaitu:

- Hulango (bidang kampung).

- Imam, Hatibi atau aparat Syara' atau yang ditokohkan, dan yang membaca salawat.

- Dua orang anak yang bertugas menjamah perut sang ibu saat diupacarakan.

- Dua orang ibu yang sementara hamil muda, yang bertugas memegang bantal dan lut ut sang ibu yang diacarakan.

- Ibu yang dibalik tirai atau podehu lo bula yang bertugas menjawab pertanyaan hulango.

3) Prosesi Pelaksanaan

a) Molone'o

Molone'o adalah mengetahui keadaan perut sang ibu yang hamil tentang usia bayinya, yang dihitung dari berhentinya haid (tiloyonga), sampai pada satu bulan. Caranya adalah dengan mengurut perut sang ibu dengan jari tengah pada kedua tangan terbuka. Peristiwa ini ditandai dengan mongadi salawati, pada hari Jumat, yang disahkan oleh hatibi atau yang ditokohkan.

Ketika masa kehamilan mencapai tujuh bulan, maka pihak keluarga akan menghubungi hulango (bidan kampung) untuk memberitahukan dan sekaligus 
memintanya menjadi pemimpin upacara molontalo. ${ }^{44}$ Selain itu, pihak keluarga juga menyampaikan undangan kepada para kerabat dan tetangga terdekat untuk ikut menghadiri upacara. ${ }^{45}$

b) Modu'oto

Modu'oto adalah mengetahui umur bayi, yang dihitung dari saat molone'o, yaitu berusia tiga bulan. Caranya adalah dengan mengurut perut sang ibu dengan tapak tangan pada sisi-sisi perut. Peristiwa ini ditandai dengan mongadi salawati, pada hari Jumat pagi sebelum embun menguap, dengan pertimbangan pada saat itu perut sang ibu masih lembut untuk diurut, agar jabang bayi tetap pada posisi yang sebenarnya. Tempat pelaksanaannya di ruang tengah (duledehu), dan ibu yang hamil diurut perutnya di atas tikar putih bersih. Pada pra-acara ini, suami istri belum diharuskan memakai busana adat, melainkan hanya dengan berpakaian muslim, atau kebaya dan batik ota'u.

c) Molontalo

Pertama-tama hulango menyiapkan bahan-bahan atau atribut adat sebagaimana yang telah diuraikan pada persiapan. Kemudian memberikan tanda (bonto) dengan alawahu tilihi pada dahi, leher, bagian bawah tenggorokan, bahu, lekukan tangan dan bagian atas telapak kaki, bawah lutut.

Sang ibu dibaringkan di atas permadani yang dilapisi dengan tikar putih, kepalanya menghadap ke Timur dan kakinya ke Barat. Seorang ibu memegang bantal dan menjaga di bagian kepalanya. Pada bagian kaki seorang ibu menjaga sambil memegang lutut dari seorang ibu yang diacarakan, posisi lut ut terlipat ke atas.

Dua orang anak (laki-laki dan perempuan) pada payu lo limutu, satu orang anak perempuan pada payu lo hulantalo, yang sudah dapat berbicara. Mereka duduk bersebelahan ( ayu lo limutu), duduk di sisi sebelah kanan dari ibu yang ditonthalo. Kedua tangan mereka tersusun di atas perut ibu yang hamil, tepat di atas ikat pinggang janur berkepang tiga.

Syara'a menanyakan kepada ibu yang di balik tirai/pemegang lalante bula (tikar terbungkus kain batik) sebagai berikut: ma ngolo hula? artinya: sudah berapa bulan? Pertanyaan ini diteruskan kepada hulango lalu dibalas oleh hulango dengan kalimat: oyinta oluwo dan seterusnya. Jawaban itu diteruskan oleh ibu di balik tirai (podehu lo bula), kepada syara'a dengan suara keras, demikian berlangsung tiga kali.

Suami yang memakai busana adat dengan keris di pinggangnya melangkahi perut sang istri tiga kali, lalu menghunus keris dan memotong ikat an anyaman silar tersebut. Setelah anyaman silar itu terputus, maka suami mengeluarkan ikatan silar tersebut, dan istri bangun menuju pintu di depan lalante bula dan suami keluar mengelilingi rumah sekali, kemudian membuang silar itu jauh-jauh. ${ }^{46}$

Selesai acara tersebut, keduanya (suami istri) kembali ke rumah, duduk berhadapan saling suap menyuapi dengan seperangkat makanan yang ada di baki yaitu nasi bilinti, dan ayam goreng, didahului dengan suami mengeluarkan telur dari perut ayam goreng.

Selanjutnya adalah pembacaan doa salawat oleh imam/hatibi atau aparat keagamaan lainnya di hadapan para undangan yang terdiri dari kerabat kedua belah

\footnotetext{
${ }^{44}$ Demsi Usman (Tokoh Pemuda), Hasil Wawancara, pada tanggal 12 Agustus 2017 di Gorontalo

${ }^{45}$ Muliyana Busala (Tokoh Pemuda), Hasil Wawancara, pada tanggal 12 Agustus 2017 di Gorontalo.

${ }^{46}$ Hadijah (Bidan Kampung), Hasil Wawancara, pada tanggal 12 Agustus 2017 di Gorontalo.
} 
pihak. Pembacaan doa salawat ini sekaligus mengakhiri rangkaian acara molontalo ini, dan sebelum bubar, suami memberikan sedekah kepada para pelaksana diiringi dengan pembagian pala'u.

\section{PENUTUP}

Wujud implementasi nilai-nilai pendidikan Islam dalam kearifan lokal masyarakat Gorontalo terkait dengan siklus kehidupan ditemukan pada beberapa makna edukatif yang diperoleh dari prosesi adat moponika/lenggota lo pohutu (pernikahan) dan molontalo (tujuh bulanan) Masing-masing dari prosesi yang terkait dengan siklus kehidupan tersebut memuat kearifan lokal yang antara lain berupa: 1) perlunya meninggalkan sifat-sifat tercela; 2) penyucian diri dari dosa lahir dan batin; 3) pentingnya menjaga kehalalan dari setiap harta yang dimiliki; 4) memperkuat pendirian, keimanan dan ketakwaan; 5) mempertahankan kesucian dan kehormatan diri; 6) kerendahan hati; 7) hidup hemat; 8) penataan diri mulai dari remaja sampai berumah tangga; 9) menjaga nama baik keluarga; 10) tidak meminta-minta; 11) keberkahan dan kebahagiaan hidup sebagai sasaran akhir; 12) penghargaan terhadap tamu dan kerabat; 13) serta pentingnya kesabaran dalam menjalani kehidupan.

\section{DAFTAR PUSTAKA}

Abdullah, Irwan, dkk., Agama dan Kearifan Lokal dalam Tantangan Global, Cet. II; Yogyakarta: Sekolah Pascasarjana UGM dan Pustaka Pelajar, 2008.

Ayatruhaedi, Kepribadian Budaya Bangsa Local Genius Jakarta: Pustaka Jaya, 1986.

Baruadi, Moh. Karmin, "Sendi Adat dan Eksistensi Sastra; Pengaruh Islam dalam Nuansa Budaya Lokal Gorontalo", el Harakah Vol.14 No. 2 Tahun 2012.

Baruadi, Moh. Karmin, "Sendi Adat dan Eksistensi Sastra; Pengaruh Islam dalam Nuansa Budaya Lokal Gorontalo", el Harakah Vol. 14 No. 2 Tahun 2017.

Botutihe, Medi dan Farhah Daulima, Tata Upacara Adat Gorontalo t.tp, 2003.

Daulima, Farhah, Ragam Upacara Adat Gorontalo Limboto: Forum Suara Perempuan MBUI Bungale, 2006.

Farhah Daulima, Tata Cara Adat Perwakinan pada Masyarakat Adat Suku Gorontalo Gorontalo: LSM Mbu'i Bungale, 2006.

Fariani, "Nilai Pendidikan dalam Kearifan Lokal Permainan Tradisional Anak Suku Batak dan Melayu", dalam Buletin Haba, Nomor 72 Banda Aceh: Balai Pelestarian Nilai Budaya, 2014.

Geriya, S. Swarsi dalam "Menggali Kearifan Lokal untuk Ajeg Bali" dalam Iun, http://www.balipos.co.id.

Gobyah, I Ketut "Berpijak pada Kearifan Lokal" dalam http://www. balipos.co.id, diakses pada tanggal 14 Desember 2016.

Ibrahim, Proses Masuk dan Berkembangnya Agama Islam di Gorontalo Gorontalo: STKIP, 2004. 
Ishak, Ajub, Hukum Perdata Islam di Indonesia dan Prakek Perkawinan dalam Bingkai Adat Gorontalo Cet. 1; Gorontalo: Sultan Amai Press, 2014.

Koentjaraningrat, Metode-metode Penelitian Masyarakat Jakarta: Gramedia, 1981. , Pengantar Antropologi Jakarta: Universitas Indonesia Press, 2004.

Madjid, Nurcholish, Doktrin dan Peradaban; Sebuah Telaah Kritis tentang Masalah Keimanan, Kemanusiaan, dan Kemodernan Jakarta: t.p., t.th.

Nani Tuloli, dkk., Ragam Upacara Tradisional Daerah Gorontalo Cet. I; Gorontalo: Sub Dinas Kebudayaan Dinas Pendidikan dan Kebudayaan Provinsi Gorontalo, 2006.

Nur, S.R., Beberapa Aspek Hukum Tata Kerajaan pada Masa Pemerintahan Eyato 1673-1679 Ujung Pandang: UNHAS Press, 1979.

Pateda, Mansyur, et. al (eds.), Pohutu Aadati Lo Hulondalo: Tata Upacara Adat Gorontalo (Hasil Seminar Adat Gorontalo, 2017) Gorontalo: Pemda Kabupaten Gorontalo Kerjasama Forum Pengkajian Islam Al-Kautsar Gorontalo, 2008.

Polontalo, Ibrahim, Upaya-upaya Pemertahanan Sistim Nilai Adat Bersendikan Syarak, Syarak Bersendikan Kitabullah sebagai Prinsip Adat Gorontalo Gorontalo: UNG, 2004.

Ramli, Muhammad, "Sinergitas Kearifan Lokal Masyarakat Bugis dalam Impelementasi Kebijakan Publik di Kabupaten Sidenreng Rappang”, Disertasi, (Makassar: Program Pascasarjana Universitas Hasanuddin, 2008.

Sartini, "Menggali Kearifan Lokal" dalam Jurnal Filsafat, Jilid 37, Nomor 2 Agustus 2004.

Sartini, "Menggali Kearifan Lokal”, h. 112; "Penjelasan Tentang 'Urf” dalam Pikiran Rakyat terbitan 6 Maret 2003.

Tuloli, Nani, Sastra dan Ilmu Sastra Bandung: Pustaka Jaya, 1994.

Willy, I. Markus, M. Dikkie Darsyah, dan Mieke Ch, Kamus Inggris IndonesiaIndonesia Inggris Surabaya: Penerbit Arloka, 1996.

\section{Sumber Wawancara}

Hadijah, Oci Toino, dan Saida Karim (Bidan Kampung), Hasil Wawancara, di Gorontalo pada tanggal 14 Juli 2017.

Ningsi Pakaya dan Asmin Usman (Tokoh Pemuda), Hasil Wawancara, di Gorontalo pada tanggal 14 Juli 2017.

Abdul Gias Suluni (Tokoh Adat), Hasil Wawancara, di Gorontalo pada tanggal 14 Juli 2017.

Demsi Usman (Tokoh Pemuda), Hasil Wawancara, pada tanggal 12 Agustus 2017 di Gorontalo

Muliyana Busala (Tokoh Pemuda), Hasil Wawancara, pada tanggal 12 Agustus 2017 di Gorontalo.

Hadijah (Bidan Kampung), Hasil Wawancara, pada tanggal 12 Agustus 2017 di Gorontalo. 
Nurhayati Tine, Musafir Pabbabari, Susdiyanto, Abd. Kadir Ahmad 